\title{
Building green supply chain management in pharmaceutical companies in Indonesia
}

\author{
Prasadja Ricardianto ${ }^{a}$, Amrulloh Ibnu Kholduna ${ }^{a}$, Khalil Ridhonudzon Fachrey ${ }^{\mathrm{a}}$, Nofrisel ${ }^{\mathrm{a}}$, Lira Agusinta $^{\mathrm{a}}$, \\ Edhie Budi Setiawan $^{a}$, Zaenal Abidin ${ }^{\mathrm{a}}$, Okin Ringan Purba ${ }^{\mathrm{a}}$, Erni Pratiwi Perwitasari ${ }^{\mathrm{a}}$, Endri Endri $^{\mathrm{b}}$
}

${ }^{a}$ Trisakti Institute of Transportation and Logistics, Jakarta, Indonesia

${ }^{b}$ Universitas Mercu Buana, Jakarta, Indonesia

\section{A B S T R A C T}

\section{Article history:}

Received October 12, 2021

Received in revised format

October 26, 2021

Accepted December 122021

Available online

December 122021

Keywords:

Green Supply Chain Management

Green Manufacturing

Green Distribution

Reverse Logistics

Pharmaceutical Company

\begin{abstract}
This study aims to analyze the contribution of Green Manufacturing and Green Distribution on improving the performance of Green Supply Chain Management (GSCM) through Reverse Logistics. The development of industry and increasing consumer concern for the environment as well as issues regarding the concept of an environmentally sound industry have forced industries to adjust in line with the GSCM concept. To make the program a success, Green Manufacturing, Green Distribution, and Reverse Logistics are assumed to be supporting the implementation process. This study uses quantitative methods, with the number of samples taken randomly as many as 70 people. The analysis was carried out using the Path Analysis method. Hypothesis testing was carried out in two stages, namely Structural Model-1 and Structural Model-2 testing to obtain each path coefficient number. The results of the study conclude that there is the contribution of Green Manufacturing, Green Distribution, and Reverse Logistics on the success of GSM implementation so that companies must always pay attention to the facilities and related policies to improve the performance of those variables.
\end{abstract}

\section{Introduction}

Pharmaceutical companies play an important role in the manufacturing industry that supports health services in Indonesia (Endri et al., 2020). The increasing attention and awareness of the environmental problems around the globe have also encouraged the pharmaceutical industry of Actavis Indonesia to implement the concept of Green Manufacturing in its business process. Waste treatment to be reused is a solution in implementing a sustainable industry because it can save costs, this is a challenge for Actavis Indonesia because there are quite a lot of unused and expired raw materials and packaging due to lack of production planning, purchasing, and sales that have not been carried out properly so that it has an impact on the accumulation of waste from the raw materials and packaging. The amount of waste that becomes unused is also an expense because Actavis Indonesia must pay to destroy the waste.

Regarding the Green Distribution process, Actavis Indonesia feels that it is still not optimal, this is partly due to the company's lack of accuracy in selecting vendors and suppliers of raw materials and packaging that still use raw materials that are less environmentally friendly, for example, such as plastic bottle packaging raw materials that are not environmentally friendly. it should be replaced with glass bottles that are more environmentally friendly, the use of outer packaging that still uses paper as the main material so that it has the potential to damage the environment. Related to this, the company needs to set standardization in the selection of suppliers to provide raw materials that are more environmentally friendly and can be recycled for reuse.

\footnotetext{
* Corresponding author Tel.: +628129204067

E-mail address: endri@mercubuana.ac.id (E. Endri)

(c) 2022 Growing Science Ltd. All rights reserved.

doi: $10.5267 /$ j.uscm.2021.12.006
} 
Reverse Logistics or Product Return activities at Actavis Indonesia are also felt to be still inefficient due to the lack of initial planning in direct sales to consumers and distributors, which can have an impact on the accumulation of a stock of old products and products that are not sold in warehouses so that it has the potential to hinder the process of entering and exiting goods that are needed interfere with production and distribution processes. Excessive product manufacture and a large number of product returns to the company, coupled with the lack of warehouse facilities, eventually lead to waste due to warehouse rental costs. The managed goods can be in the form of products or packaging, such as End of Life (EOL) products, end of use products, product recalls, returns for stock balancing, and returns for unsold products.

Supply Chain according to Christopher and Holweg (2011) states that network of organizations with upstream and downstream involvement in different processes and activities to generate value in the form of products and services used by end consumers. Supply Chain Management is the activity of managing the flow of information, products, and services throughout the network, be it customers, companies to suppliers (Russell \& Taylor, 2016). According to Ribeiro and BarbosaPovoa (2018), Supply Chain Management is a network of suppliers, manufacturing, assembly, distribution, and logistics facilities that form the purchasing function of materials, the transformation of materials into semi-finished goods and finished products, and the distribution process of materials. these products to consumers. Environmentally conscious supply chain management aims to consider the final and present environmental impacts of all products and processes to protect the natural environment (Natalia \& Astuario, 2015).

The model designed by the Supply Chain Council (SCC), integrates three main elements in management, namely Business Process Reengineering, Benchmarking, and process measurements into the traffic function framework in the Supply Chain (Council, 2008; Natalia et al., 2014). The GSCM model has been narrowed down from three important elements into five main components in managing a process, namely Plan, Source, Make, Deliver, and Return (Natalia \& Astuario, 2015), where these processes represent all GSCM activities from upstream to downstream. Downstream in detail, to define and categorize the processes that build the metrics of measurement indicators needed in measuring GSCM performance. Thus, this model is appropriate as a tool to manage the environmental impact of a supply chain. Manufacturing is an input-output system, where resources are inputs and are transformed through the manufacturing process into semi-finished products or products (Sangwan \& Mittal, 2015). Another example according to Zhu et al. (2010) states that a sample of Japanese manufacturers implements four GSCM practices such as; environmentally friendly purchasing, customer cooperation with environmental considerations, environmentally friendly design, and investment recovery at the same level when compared with Chinese manufacturers. Whereas in China, according to the results of research of Dong et al. (2014) concluded that GSCM practices help improve the company's environmental performance, especially in terms of reducing pollutant emissions and increasing employee environmental awareness. Previous research by Candrasa et al. (2020) shows that company managers in Thailand, according to company regulations, have provided incentives to employees who implement GSCM.

Thus, GSCM can be synthesized as a concept that integrates environmental thinking into supply chain management, product design, procurement and selection of raw materials, manufacturing processes, and delivery of final products to consumers. The GSCM model is further divided into five variable dimensions, namely; (1) Plan, (2) Source, (3) Make, (4) Deliver, and (5) Return.

Green Manufacturing is closely related to sustainable manufacturing. Sustainability can be obtained by applying the Green concept (Pahala et al., 2021). The Green concept includes the process of making products with minimal use of materials and processes that minimize negative impacts on the environment, save energy and natural resources, are safe for employees, communities, and consumers while retaining economic value (Dornfeld, 2014). According to (Dam \& Petkova, 2014; De Giovanni \& Vinzi, 2012; Srivastava, 2007), Green Manufacturing is defined as a process of production with low environmental due to the use of efficient inputs, so that it produces little or no waste or pollution. Harrison et al. (2019) added that Green Manufacturing addresses especially the environmental consequences through the whole of the product life cycle, including the unsold or returned products in the market. Through the study aspects of Green Design, Green Production, 3R (Reduce, Reuse, and Recycle), in this case, the output of the Green Manufacturing process will improve the process of GSCM. Green Manufacturing will minimize the production process with low pollution impact, be more efficient and produce little or no waste or pollution, as well as reduce raw material costs so that production efficiency will increase. Research on Green Manufacturing in Indonesia is still not done much, especially about how to increase the knowledge of all industrial circles about green and how existing environmental standards or regulations can be applied optimally in Indonesia. Research by Tarigan et al. (2021) in Indonesia has been conducted regarding the measurement of Green Manufacturing activity in companies with a lot of waste disposal so that they can continue to develop their business properly and provide recommendations for improvement based on the results of performance measurements that have been carried out. So, the concept of Green Manufacturing is an effort to minimize the production process with a low pollution impact. The use of efficient material leads to production that yields little or even no waste or pollution. In addition, the concept of Green Manufacturing also has the potential to reduce raw material costs so that production efficiency will increase. For that matter, the variable dimensions include; 1) Green Design, 2) Green Production, and 3) 3R concept (Reduce, Reuse, \& Recycle). 
According to Kotler and Keller (2016) distribution is a set of organizations that depend on each other in providing a product for use or consumption by consumers/users. Achrol and Etzel (2003) say that distribution channels consist of a series of institutions that carry out all activities used to distribute products and their ownership status from producers to consumers or business users. According to Srivastava (2007) activities in Green Distribution include saving in packaging, including time to unpack, the use of environmentally safe materials, optimizing the use of inputs, and encouraging recycling the waste. Cherrafi et al. (2017) state that Green Distribution involves three main things: Delivery of products by implementing efficient shipping standards and routes, Criteria for suppliers and partners with conceptual and sustainable standards, and Efficient use of energy in the distribution process that can reduce pollution and energy saving. Another finding by Sallnäs and Björklund (2020) shows that consumers currently have limited possibilities to contribute to Green Distribution, one of the reasons is the limited communication between logistics service providers, e-tailers, and consumers. In this context, Green Distribution can be defined as product distribution activities to customers in Supply Chain activities that pay attention to environmental impacts with three variable dimensions, namely: 1) product delivery 2) supplier criteria 3) energy use in the distribution process

Reverse Logistics creates physical and non-physical value by supporting companies get value from used products, creating extra value through improving product life cycles, increasing satisfaction and loyalty of customers by giving more attention to the products and repair merchandise (Aitken \& Harrison, 2013; Dowlatshahi, 2000). Lehtinen and Ahola (2010) say that using Reverse Logistics to measure the supply chain performance, they show how companies may achieve competitive advantage by calculating the efficiency and effectiveness of their operations. Toke et al. (2012) state that Reverse Logistics is the process of taking products from end consumers to increase value and proper disposal. All activities to reduce costs, raise profits, minimize impacts on the environmental problems, shorten liabilities, and better customer relationships (Chavez et al., 2013). In addition, research findings Khor and Udin (2013) from Malaysia explain that green product design and Reverse Logistics product disposition are interrelated, companies must take a pro-environmental approach to generate benefits from resources that are wasted as waste. Another finding in Malaysia by Abdullah et al. (2014) on the contrary shows that the adoption rate of Reverse Logistics among Malaysian producers is very low. Reverse Logistics in this case can be defined as activities to extract value from used goods, create added value through environmentally friendly and green activities, by repairing, or recycling products (Widiyanto et el., 2021). The dimension used is Return Product.

The results of this study can be used as a reference to improve theoretical and empirical understanding of GSCM in logistics companies in general in Indonesia. This research is also useful as additional literature material to broaden the discourse and insight about Logistics activities that are environmentally friendly and acceptable for implementation in every company, manufacturing company, especially the pharmaceutical sector in Indonesia.

Furthermore, the proposed hypotheses are as follows:

$\mathbf{H}_{1}$ : Green Manufacturing $\left(X_{1}\right)$ has a direct contribution to $\operatorname{GSCM}(Y)$.

$\mathbf{H}_{2}$ : Green Distribution $\left(X_{2}\right)$ has a contribution to $\operatorname{GSCM}(Y)$.

$\mathbf{H}_{3}$ : Reverse Logistics $\left(X_{3}\right)$ has a direct contribution to GSCM $(Y)$.

$\mathbf{H}_{4}$ : Green Manufacturing $\left(X_{1}\right)$ has a direct contribution to Reverse Logistics $\left(X_{3}\right)$.

$\mathbf{H}_{5}$ : Green Distribution $\left(X_{2}\right)$ has a direct contribution to Reverse Logistics $\left(X_{3}\right)$.

Fig. 1 describes the conceptual framework of this research with four research hypotheses based on the research model.

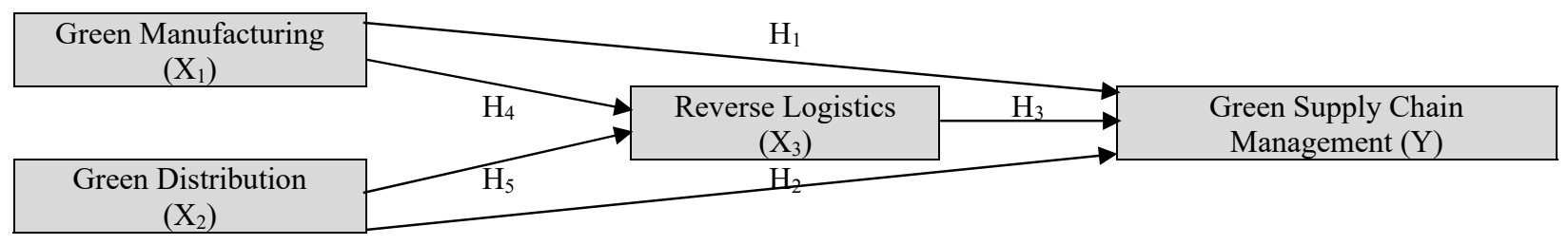

Fig. 1. Research Model

\section{Research Methods}

The population in this study consisted of staff, supervisors, and managers from various departments, namely SCM, Quality, Information Technology, Warehouse, and Production. The research unit is a pharmaceutical company, namely Actavis Indonesia. From 230 people from five existing departments, 70 samples were taken using Stratified Proportional Random Sampling. Research data were collected through a questionnaire using a Likert scale technique. The analysis method uses Path Analysis, with tests such as validity, reliability, classical assumption tests. Data analysis was performed using the regression method, including correlation test, determination test, F-test, and t-thesis test (Ricardianto et al., 2022). In the end, testing is carried out through the path analysis method consisting of Structural Model-1, Structural Model-2, and Path 
Coefficients. The indirect contribution significance test was carried out using the z-statistical formula developed by Sobel (Sobel, 1982).

\section{Results and Discussion}

\subsection{Hypothesis testing}

1. Analysis on Sub-structure One_Regression Test

GSCM Variable Determination Test

Based on statistical calculations, it shows that the multiple linear regression model for the first equation shows a coefficient of determination of 0.649 or $64.9 \%$ which means that the Green Manufacturing, Green Distribution, Reverse Logistics, and GSCM variables is $64.9 \%$.

\section{GSCM Variable F-test}

Based on statistical calculations, the F-statistic is greater than the F-table or $43.563>2.75$ and can also be seen in the probability value smaller than the significance level $(\alpha) 5 \%$ or $0.000000<0.05$. So, it can be concluded that the variables of Green Manufacturing, Green Distribution, and Reverse Logistics simultaneously contribute to GSCM.

\section{GSCM Variable t-test}

The T-test is used to test the significance of each independent variable, namely Green Manufacturing, Green Distribution, and Reverse Logistics simultaneously contributing Green Supply Chain Management. Based on statistical calculations, tstatistics is greater than t-table or 1,859 > 1,670 (X1), 2,448 > 1,670 (X2) and 3,465 > 1,670 (X3), meaning that these three variables contribute to GSCM.

2. Analysis on Sub-structure 2 Regression Test

\section{GSCM Variable Determination Test}

Based on statistical calculations, the coefficient of determination is 0.748 or $74.8 \%$ which means that the contribution of Green Manufacturing and Green Distribution variables to Reverse Logistics at PT Actavis Indonesia is $74.8 \%$.

\section{GSCM Variable F-test}

Based on statistical calculations, the F-statistic is greater than the F-table or $103.210>3.14$ and can also be seen in the probability value smaller than the significance level $(\alpha) 5 \%$ or $0.000000<0.05$.

\section{GSCM Variable t-test}

T-test to test the significance of each independent variable, namely Green Manufacturing and Green Distribution simultaneously contributing Reverse Logistics. So, it is obtained that the t-statistic is greater than t-table or 7,309 $>1,670$ (X1), 5,992>1,670 (X2), meaning that these two variables contribute to Reverse Logistics.

\section{Path Analysis Results}

\section{Table 1}

Path Analysis Results

\begin{tabular}{|c|c|c|c|c|c|c|}
\hline $\begin{array}{l}\text { Direct Contribution } \\
\text { Between Variables }\end{array}$ & $\begin{array}{c}\text { Path } \\
\text { Coefficient (pij) }\end{array}$ & $\begin{array}{l}\text { Standard } \\
\text { Error(sbi) }\end{array}$ & $\mathbf{t}_{\text {-statistic }}$ & $\rho$ - value & Conclusion & $\mathrm{R}^{2}$ \\
\hline Green Manufacturing on Reverse Logistics $\left(\rho X_{1} X_{3}\right)$ & 0.538 & 0.043 & 7.309 & 0.000 & Significant & \multirow{3}{*}{0.755} \\
\hline Green Distribution on Reverse Logistics $\left(\rho \mathrm{X}_{2} \mathrm{X}_{3}\right)$ & 0.441 & 0.044 & 5.992 & 0.000 & Significant & \\
\hline Green Manufacturing on GSCM $\left(\rho \mathrm{X}_{1} \mathrm{Y}\right)$ & 0.123 & 0.129 & 1.859 & 0.004 & Significant & \\
\hline Green Distribution on $\operatorname{GSCM}\left(\rho \mathrm{X}_{2} \mathrm{Y}\right)$ & 0.263 & 0.124 & 2.448 & 0.003 & Significant & \multirow{2}{*}{0.664} \\
\hline Reverse Logistics on GSCM $\left(\rho \mathrm{X}_{3} \mathrm{Y}\right)$ & 0.499 & 0.276 & 3.465 & 0.001 & Significant & \\
\hline
\end{tabular}

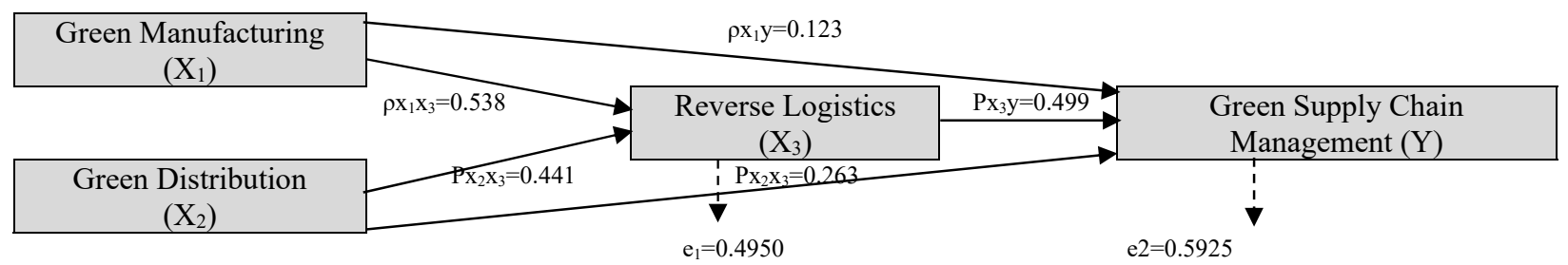

Fig. 2. Path Analysis 
The direct contribution is the direct contribution of the variables $\mathrm{X} 1, \mathrm{X} 2$, and $\mathrm{X} 3$ on $\mathrm{Y}$, can simply be presented as follows, the contribution of Green Manufacturing on Green Supply Chain Management is 0.123; contribution of Green Distribution on Green Supply Chain Management is 0.263 , and contribution of Reverse Logistics on Green Supply Chain Management is 0.499 .

Statistical Results of Direct Contribution Between Variables

Table 2

Results of Direct Contribution

\begin{tabular}{|c|c|c|c|c|c|c|}
\hline $\begin{array}{l}\text { Direct Contribution } \\
\text { Between Variables }\end{array}$ & $\begin{array}{c}\text { Path Coefficient } \\
\text { (pij) }\end{array}$ & $\begin{array}{c}\text { Standard Error } \\
\text { (sbi) }\end{array}$ & $\mathbf{t}_{\text {-statistic }}$ & $\rho$ - value & Conclusion & $\mathbf{R}^{2}$ \\
\hline Green Manufacturing on GSCM $\left(\rho X_{1} Y\right)$ & 0.123 & 0.129 & 1.859 & 0.004 & Significant & \\
\hline Green Distribution on GSCM $\left(\rho \mathrm{X}_{2} \mathrm{Y}\right)$ & 0.263 & 0.124 & 2.448 & 0.003 & Significant & \\
\hline Reverse Logistics on GSCM $\left(\rho \mathrm{X}_{3} \mathrm{Y}\right)$ & 0.499 & 0.276 & 3.465 & 0.001 & Significant & 0.664 \\
\hline
\end{tabular}

The direct contribution between variables on the three hypotheses was concluded to be significant (Table 3).

Significance Test Results of Direct and Indirect Contribution Between Variables

Table 3

Results of Indirect Contribution

\begin{tabular}{lccc}
\hline $\begin{array}{l}\text { Direct contribution } \\
\text { between variables }\end{array}$ & Path Coefficient $\left(\mathbf{\rho} \mathbf{X}_{\mathbf{1}} \mathbf{X}_{\mathbf{3}}\right)$ & Path Coefficient $\left(\mathbf{\rho} \mathbf{X}_{\mathbf{3}} \mathbf{Y}\right)$ & Multiplication of Path Coefficient \\
\hline Green Manufacturing on GSCM $\left(\rho \mathrm{X}_{1} \mathrm{Y}\right)$ & 0.538 & 0.499 & 0.2683 \\
Green Distribution on GSCM $\left(\rho \mathrm{X}_{2} \mathrm{Y}\right)$ & 0.441 & 0.499 & 0.2201 \\
\hline
\end{tabular}

3. Indirect effect of exogenous variables on endogenous variables (Table 3)

The indirect of Green Manufacturing on Green Supply Chain Management through Reverse Logistics is the product of the path coefficients is 0.2683. Meanwhile, the indirect of Green Distribution on Green Supply Chain Management through Reverse Logistics is the product of the path coefficient is 0.2201 . The results of the first stage of the analysis of Green Manufacturing, Green Distribution, and Reverse Logistics on GSCM is 0.123 with a standard error of 0.004, the t-statistic value is $1.859>1.670$, then $\mathrm{H} 0$ is rejected and $\mathrm{H} 1$ is accepted. 0.263 with a standard error of 0.003 and the is significant with a t-statistic value of $2.448>1.670$, then $\mathrm{H} 0$ is rejected and $\mathrm{H} 2$ is accepted, 0.499 with a standard error of 0.001 and the is significant with a t-statistic value of $3.465>1.670$, then $\mathrm{H} 0$ is rejected and $\mathrm{H} 3$ is accepted, meaning that there is a contribution of Green Manufacturing, Green Distribution, and Reverse Logistics to GSCM.

\section{Direct Contribution Between Variables in Total}

The total is the sum of the direct and indirect s, as follows (Table 4). The total of the Green Manufacturing variable on Green Supply Chain Management is 0.3915. Meanwhile, the total of the Green Distribution variable on Green Supply Chain Management is 0.4831 .

Table 4

Results of Total

\begin{tabular}{|c|c|c|c|}
\hline $\begin{array}{r}\text { Direct Contribution } \\
\text { Between Variables }\end{array}$ & Path Coefficient $\left(\rho X_{1} Y\right)$ & $\begin{array}{l}\text { Multiplication of Path Coefficient } \\
\left(\rho \mathrm{X}_{1} \mathrm{X}_{3}\right) \\
\left(\rho \mathrm{X}_{3} \mathrm{Y}\right) \\
\end{array}$ & Total Path Coefficient \\
\hline Green Manufacturing on GSCM $\left(\rho X_{1} Y\right)$ & 0.538 & $(0.123 \times 0.499)$ & 0.3915 \\
\hline Green Distribution on GSCM $\left(\rho \mathrm{X}_{2} \mathrm{Y}\right)$ & 0.441 & $(0.441 \times 0.499)$ & 0.4831 \\
\hline
\end{tabular}

5. Indirect Contribution Significance Test with Sobel Test

Based on the results of calculations using the Sobel test, it was found that $\mathrm{z}$ is smaller than $\mathrm{t}$-table or $0.5706<1.670$, so it can be concluded that there is no indirect contribution of Green Distribution on Green Supply Chain Management through Reverse Logistics (Table 4).

Table 4

Summary of Significant Test Based on Sobel Test

\begin{tabular}{ccccc}
\hline Indirect Contribution & Path Coefficient (pij) & $\begin{array}{c}\text { Standard of Error } \\
\text { (sbi) }\end{array}$ & $\mathbf{Z}_{\text {-statistic }}$ & $\mathbf{t}_{\text {-statistic }}$ \\
\hline $\begin{array}{c}\text { Green Manufacturing on GSCM } \\
\text { Through Reverse Logistics }\end{array}$ & 0.538 & 0.043 & 1.795 & 1.670 \\
$\begin{array}{c}\text { Green Distribution on GSCM } \\
\text { Through Reverse Logistics }\end{array}$ & 0.441 & 0.044 & 0.570 & Significant \\
\hline
\end{tabular}




\subsection{Hypothetical Testing}

\section{The Contribution of Green Manufacturing on Green Supply Chain Management (GSCM)}

Based on the results of the study that the contribution of Green Manufacturing on GSCM is 0.123 with a standard error of 0.004 and the contribution is significant with a t-statistic value of $1.859>1.670$ greater than t-table, then $\mathrm{H} 0$ is rejected and $\mathrm{H} 1$ is accepted, meaning that there is a contribution between Green Manufacturing on GSCM. Substantially that Green Manufacturing has a relationship in implementing GSCM seen in the production process, reducing the impact and efficiency on the environment and producing less waste and pollution so that it can reduce production costs, work safety costs, and minimize the negative contribution on the environment wherein theory and the argument that Green Manufacturing basically can occur and be implemented even though GSCM has not been implemented, but Green Manufacturing is a very influential substance in implementing the GSCM concept which can be seen from GSCM activities. The results of the study Afum et al. (2020) in Ghana, explaining that Green Manufacturing has a strong positive contribution on some essential field performances such as economic, environmental, and social performances. Green Manufacturing has a significant positive contribution to GSCM on contribution an integrated basis. In addition, GSCM also plays a mediating role between Green Manufacturing practices and sustainable performance. Thus, the results of this study are in line with previous theoretical studies and related research results. This means that there is a significant direct contribution between the Green Manufacturing variable on GSCM.

\section{The Contribution of Green Distribution on Green Supply Chain Management}

Based on the results of the study that the Green Distribution of GSCM at Actavis Indonesia was 0.263 with a standard error of 0.003 and the contribution was significant with a t-statistic value of $2.448>1.670$ greater than t-table, then $\mathrm{H} 0$ was rejected and $\mathrm{H} 2$ was accepted, meaning that there was contribution between Green Distribution on GSCM at Actavis Indonesia. In substance, that Green Distribution has a relationship in implementing GSCM at Actavis Indonesia, it can be seen in the distribution process carried out by efficient and effective product delivery so that costs and energy can be reduced properly, the selection of suppliers or work partners by environmental sustainable standards can reduce the use of where in theory and argumentation that Green Distribution can occur and be applied even though GSCM has not been implemented, but Green Distribution is one of the important substances in implementing GSCM which can be seen from GSCM activities. Another finding in Italy by Perotti et al. (2012) found also useful in advising companies to modify the GSCM adopted within their companies to achieve the required targets, or identify the most suitable GSCM to be implemented, point of view of the Green process. Distribution. Thus, the results of this study are in line with previous theoretical studies and related research results. This means that there is a significant direct contribution between Green Distribution on GSCM.

\section{The Contribution of Reverse Logistics on Green Supply Chain Management}

Based on the results of the research that the contribution of Reverse Logistics on GSCM at Actavis Indonesia is 0.499 with a standard error of 0.001 and the contribution is significant with a t-statistic value of $3.465>1.670$ greater than t-table, then $\mathrm{H} 0$ is rejected and $\mathrm{H} 3$ is accepted, meaning that there is the contribution of Reverse Logistics on GSCM at Actavis Indonesia. In substance, that Reverse Logistics has a relationship in implementing GSCM at Actavis Indonesia, it can be seen that based on the reference to the return product scale where this is done effectively, not only can reduce waste that will have an impact on the environment, but effective Reverse Logistics management can reduce costs. In addition to that, it can also have an impact on increasing company profitability and can even improve the public image of the company wherein theory and the argument that Reverse Logistics can occur and be implemented even though GSCM has not been implemented, Reverse Logistics is one of the important substances and liaisons in implementing GSCM which can be seen from GSCM activities. This finding supports the study by Aćimović et al. (2020) in Serbia, showing that the contribution of Reverse Logistics on the competitiveness of GSCM depends on the product return options and is especially negative for consumers, as the perceived quality of each of the three return options is considered lower than the new product. The practical value of this research is that it shows a clear sign for companies to step up their efforts to raise future awareness about the importance of Green Manufacturing towards Reverse Logistics among business partners, but also end consumers by implementing GSCM. GSCM in Reverse Logistics aims to minimize by-products from ending up in landfills. This research by Aitken \& Harrison (2013), Chen et al. (2019), and Mutingi (2014) shows that stakeholders are better at making their pricing and manufacturing decisions in Cooperation as well as improving the environmental, social, and economic performance of GSCM. However, the findings related to the GSCM research by Hazen et al. (2011) state that consumers perceive products made through some implementation of Green Reverse Logistics as inferior to new products in terms of quality. Thus, the results of this study are in line with previous theoretical studies and related research results. This means that there is a significant direct contribution between the Reverse Logistics on GSCM.

\section{The Contribution of Green Manufacturing on Green Supply Chain Management Through Reverse Logistics}

The results of the research show that the indirect contribution of Green Manufacturing on Green Supply Chain Management at Actavis Indonesia through Reverse Logistics is 0.538 with a standard error of 0.000 and the contribution is significant with 
a t-statistic value of 1.795 , greater than the t-table value of 1.670 , then $\mathrm{H} 0$ is rejected and $\mathrm{H} 4$ is accepted, meaning that there is an indirect contribution of Green Manufacturing on GSCM at Actavis Indonesia through Reverse Logistics. This study supports research by Herrmann et al (2021) that Green Distribution on Reverse Logistics has a significant contribution in implementing the GSCM concept. To realize the concept of an environmentally sound industry, companies need to implement the concept of a Green Distribution on Supply Chain Management Strategy that focuses on sustainability. With the implementation of Strategy Distribution and GSCM concepts, the company will have the opportunity to increase the efficiency of Reverse Logistics logistics activities to reduce the company's total logistics costs. Thus, the results of this study are in line with previous theoretical studies and related research results. This means that there is a significant indirect contribution between the Green Manufacturing variable on GSCM through Reverse Logistics.

\section{The Contribution of Green Distribution on Green Supply Chain Management Through Reverse Logistics}

Based on the results of the study that the indirect contribution of Green Distribution on GSCM through Reverse Logistics is 0.263 and the is not significant with a t-count of 0.570 , smaller than the t-table value of 1.670 . The analysis proves that H0 is approved and H5 is rejected, it confirms that there is no indirect contribution of Green Distribution on GSCM through Reverse Logistics. From the information above, the indirect contribution of the Green Manufacturing variable on GSCM through Reverse Logistics and the Green Distribution variable on GSCM through Reverse Logistics can be concluded that Green Manufacturing contributes to Reverse Logistics due to the Manufacturing process that is by the supporting concepts in the implementation of GSCM through the system. Reverse Logistics is going well. However, the Green Distribution variable for GSCM through Reverse Logistics can be concluded that it does not make a good due to the purchase of raw materials that are still using materials that are not environmentally friendly and distribution channels that are still not properly scheduled, causing energy waste by Actavis Indonesia. Thus, the results of this study are in line with previous theoretical studies and related research results. This means that there is an indirect and insignificant contribution between the Green Distribution variables on GSCM through Reverse Logistics. From the results of previous calculations, the direct contribution between the variables of Green Manufacturing, Green Distribution and Reverse Logistics on Green Supply Chain Management at Actavis Indonesia, has the order of Reverse Logistics of 0.499 or $49.9 \%$, Green Distribution of 0.263 or $26.3 \%$ and Green Manufacturing of 0.123 or $12.3 \%$. The results of the research show that when Green Supply Chain Management can be seen firstly because Reverse Logistics has been running well and neatly, secondly it can be seen that Green Distribution is by the plan and thirdly by looking at Green Manufacturing that has been carried out properly and in accordance.

\section{Conclusion}

To build and implement GSCM through the Green Manufacturing process, pharmaceutical companies, in particular, must improve facilities such as using environmentally friendly and energy-efficient machines, in this case, the use of machines through electrical energy is highly recommended because it can reduce the use of solar energy in machines which is a waste of resources nature if it is implemented then the performance of GSCM will increase. In improving waste filtration and reuse of waste, it is necessary to add a waste pool so that waste filtering can be carried out maximally and reduce pollution, in the reuse of waste products, selection and standardization of purchases from suppliers for raw materials and packaging can be carried out so that the raw materials and packaging can be decomposed properly good, does not pollute the environment and can be reused.

In planning production, buying and selling must be carried out properly and measurably so that the products that have been produced do not exceed sales needs, this can reduce the potential for product build-up in the warehouse and reduce the potential for re-products destroying products whose costs are quite high. Therefore, planning must be measured properly and precisely. In building and implementing GSCM, it is strongly contributions by Green Manufacturing, Green Distribution, and Reverse Logistics. This is evident from the results of research that has been proven in the description above which has a positive and significant contributed to GSCM. Therefore, the implications for the company must always pay attention to facilities, environment, and policies related to Green Manufacturing, Green Distribution, Reverse Logistics, and GSCM.

\section{References}

Abdullah, N., Halim, N. A., \& Yaakub, S. (2014). Reverse logistics: pressure for adoption and the impact on firm's performance. International Journal of Business and Society, 15(1), 151-170.

Achrol, R. S., \& Etzel, M. J. (2003). The structure of reseller goals and performance in marketing channels. Journal of the Academy of Marketing Science, 31(2), 146-163. https://doi.org/10.1177/0092070302250899

Aćimović, S., Mijušković, V., \& Rajić, V. (2020). (2020). Aćimović, S., Mijušković, V., The impact of reverse logistics onto green supply chain competitiveness evidence from Serbian consumers. International Journal of Retail \& Distribution Management., 48(9). https://doi.org/10.1108/IJRDM-04-2019-0142

Afum, E., Osei-Ahenkan, V. Y., Agyabeng-Mensah, Y., Owusu, J. A., Kusi, L. Y., \& Ankomah, J. (2020). Green manufacturing practices and sustainable performance among Ghanaian manufacturing SMEs: the explanatory link of green supply chain integration. Management of Environmental Quality: An International Journal., 31(6), 1457-1475. 
https://doi.org/10.1108/MEQ-01-2020-0019

Aitken, J., \& Harrison, A. (2013). Supply governance structures for reverse logistics systems. International Journal of Operations and Production Management, 33(6), 745-764. https://doi.org/10.1108/IJOPM-10-2011-0362

Candrasa, L., Cen, C. C., Cahyadi, W., Cahyadi, L., \& Pratama, I. (2020). Green Supply Chain, Green Communication and Firm Performance: Empirical Evidence from Thailand. Systematic Reviews in Pharmacy, 11(2), 398-406.

Chavez, R., Gimenez, C., Fynes, B., Wiengarten, F., \& Yu, W. (2013). Internal lean practices and operational performance: The contingency perspective of industry clock speed. International Journal of Operations \& Production Management., 33(5), 562-588. https://doi.org/10.1108/01443571311322724

Chen, D., Ignatius, J., Sun, D., Zhan, S., Zhou, C., Marra, M., \& Demirbag, M. (2019). Reverse logistics pricing strategy for a green supply chain: A view of customers' environmental awareness. International Journal of Production Economics, 2017, 197-210. https://doi.org/10.1016/j.ijpe.2018.08.031

Cherrafi, A., El Fezazi, S., Govindan, K., Garza-Reyes, J. A., Mokhlis, A., \& Benhida, K. (2017). A framework for the integration of Green and Lean Six Sigma for superior sustainability performance. International Journal of Production Research, 55(15), 4481-4515. https://doi.org/10.1080/00207543.2016.1266406

Christopher, M., \& Holweg, M. (2011). , "Supply Chain 2.0”: managing supply chains in the era of turbulence. International Journal of Physical Distribution \& Logistics Management, 41(1), 63-82. https://doi.org/10.1108/09600031111101439

Council, S. C. (2008). Supply chain operations reference model. Overview of SCOR Version, 5(0).

Dam, L., \& Petkova, B. N. (2014). The impact of environmental supply chain sustainability programs on shareholder wealth. International Journal of Operations \& Production Management., 34(5), 586-609. https://doi.org/10.1108/IJOPM-102012-0482

De Giovanni, P., \& Vinzi, V. E. (2012). Covariance versus component-based estimations of performance in green supply chain management. International Journal of Production Economics, 135(2), 907-916. https://doi.org/10.1016/j.ijpe.2011.11.001

Dong, Y., Liu, X., \& Dong, Y. (2014). Green supply chain management and the induced performance changes of companies in the Yangtze River delta of China. Asian Journal of Management Science and Applications, 1(2), 141-158. https://doi.org/10.1504/AJMSA.2014.063377

Dornfeld, D. A. (2014). Moving towards green and sustainable manufacturing. International Journal of Precision Engineering and Manufacturing-Green Technology, 1(1), 63-66. https://doi.org/10.1007/s40684-014-0010-7

Dowlatshahi, S. (2000). Material selection and product safety: theory versus practice. Omega, $28(4)$, $467-480$. https://doi.org/10.1016/S0305-0483(99)00065-1

Endri, E., Lisdawati., Susanti, D., Hakim, L., \& Sugianto, S. (2020). Determinants of Profitability: Evidence of the Pharmaceutical Industry in Indonesia. Systematic Reviews in Pharmacy, 11(6), 587 597. DOI: 10.31838/srp.2020.6.91

Harrison, A., Skipworth, H., van Hoek, R. I., \& Aitken, J. (2019). Logistics management and strategy: competing through the supply chain. London: Pearson Education.

Haryanti, S. D. (2018). Analisis Kinerja Aktivitas Green Manufacturing Dengan Menggunakan Metode Green Supply Chain Operation Reference (Green Scor)(Studi Kasus: Kusuma Jaya Batik). [Thesis\} Program Studi Teknik Industri Fakultas Teknologi Industri Universitas Islam Indonesia Yogyakarta.

Hazen, B. T., Cegielski, C., \& Hanna, J. B. (2011). Diffusion of green supply chain management: Examining the perceived quality of green reverse logistics. The International Journal of Logistics Management, 22(3), 373-389. https://doi.org/10.1108/09574091111181372

Herrmann, F.F., Barbosa-Povoa, A.P., Butturi, M.A., Marinelli, S., \& Sellitto, M.A. (2021). Green Supply Chain Management: Conceptual Framework and Models for Analysis. Sustainability, 13, 8127. https://doi.org/10.3390/ su13158127

Khor, K. S., \& Udin, Z. M. (2013). Reverse logistics in Malaysia: Investigating the green product design and resource commitment. Resources, Conservation and Recycling, 81, 71-80. https://doi.org/10.1016/j.resconrec.2013.08.005

Kotler, P., \& Keller, K. L. (2016). Marketing Management (15th Eds.). Upper Saddle River, N.J: Prentice-Hall International.

Lehtinen, J., \& Ahola, T. (2010). Is performance measurement suitable for an extended enterprise? International Journal of Operations and Production Management, 28(4), 467-480. https://doi.org/10.1108/01443571011018707

Mutingi, M. (2014). The impact of reverse logistics in green supply chain management: a system dynamics analysis $186-201$. International Journal of Industrial and Systems Engineering, 17(2), 186-201. https://doi.org/10.1504/IJISE.2014.061993

Natalia, C., \& Astuario, R. (2015). Penerapan model green SCOR untuk pengukuran kinerja green supply chain. Jurnal Metris, 16(2), 97-106.

Natalia, N., Putra, A. S., \& Melati, I. (2014). Measurement of Customer Loyalty through Experiential Marketing, Service Quality, and Brand Image Analysis with Customer Value as Variable Intervening. Journal of Business Strategy and Execution, 6(2), 220-235.

Pahala, Y., Widodo, S., Kadarwati., Azhari, M., Muliyati., Lestari, N.I., Madjid, S.A., Sidjabat, S., Limakrisna, N., \& Endri, E. (2021). The effects of service operation engineering and green marketing on consumer buying interest. Uncertain Supply Chain Management, 9(3), 603-608. https://doi: 10.5267/j.uscm.2021.5.011

Perotti, S., Zorzini, M., Cagno, E., \& Micheli, G. J. (2012). Green supply chain practices and company performance: the case of 3PLs in Italy. International Journal of Physical Distribution \& Logistics Management., 42(7), 640-672. https://doi.org/10.1108/09600031211258138

Ribeiro, P.J., \& Barbosa-Povoa, A. (2018). Supply Chain Resilience: Definitions and quantitative modeling approaches - A 
literature review. Computers and Industrial Engineering., 115, 109-122. https://doi.org/10.1016/j.cie.2017.11.006

Ricardianto, P., Wibowo, H., Agusinta, L., Abdurachman, E., Suryobuwono, A., Fachrial, P., Setiawan, A., Rafi, S., Maemunah, S \& Endri, E. (2022). Determinants of airport train operational performance. International Journal of Data and Network Science, 6(1), 91-98. doi: 10.5267/j.ijdns.2021.9.019

Russell, R. S., \& Taylor, B. M. (2016). Operations and Supply Chain Management (9th Eds). New Jersey, USA: John Wiley and Sons Inc.

Sallnäs, U., \& Björklund, M. (2020). Consumers' contribution to the greening of distribution-exploring the communication between logistics service providers, e-tailers, and consumers. International Journal of Retail \& Distribution Management., 48(11), 1177-1193. https://doi.org/10.1108/IJRDM-07-2019-0213

Sangwan, K. S., \& Mittal, V. K. (2015). A bibliometric analysis of green manufacturing and similar frameworks. Management of Environmental Quality, 26(4), 566-587. https://doi.org/10.1108/MEQ-02-2014-0020

Sobel, M. E. (1982). Asymptotic confidence intervals for indirect s in structural equation models. Sociological Methodology, $13,290-312$.

Srivastava, S. K. (2007). Green supply-chain management: A state-of-the-art literature review. International Journal of Management Reviews, 9(1), 53-80. https://doi.org/10.1111/j.1468- 2370.2007.00202.x

Tarigan, Z.J.H., Siagian, H., \& Jie, F. (2021). Impact of Enhanced Enterprise Resource Planning (ERP) on Firm Performance through Green Supply Chain Management. Sustainability, 13, 4358. https://doi.org/ 10.3390/su13084358

Toke, L. K., Gupta, R. C., \& Dandekar, M. (2012). An empirical study of green supply chain management in Indian perspective. International Journal of Applied Sciences and Engineering Research, 1(2), 372-383.

Widiyanto, P., Jaya Sakti, R.F., Setiawan, E.B., Manfaluthy, M., Suryaningsih, L., Ricardianto, P., Kamar, K., \& Endri, E. (2021). The Relationship between Service Quality, Timeliness of Arrival, Departure Flip Ship Logistics and People and Customer Satisfaction: A Case in Indonesia. Academy of Entrepreneurship Journal, 27(6), 1-10.

Zhu, Q., Geng, Y., Fujita, T., \& Hashimoto, S. (2010). Green supply chain management in leading manufacturers: Case studies in Japanese large companies. Management Research Review, 33(4), 380-392. https://doi.org/10.1108/01409171011030471 
(C) 2022 by the authors; licensee Growing Science, Canada. This is an open access article distributed under the terms and conditions of the Creative Commons Attribution (CC-BY) license (http://creativecommons.org/licenses/by/4.0/). 